\title{
Tragacanth Gum As Local Alternatives To Improve Viscosity And Filtration Control
}

\author{
Dr.Faleh H.M. Almahdawi ${ }^{*}$, Dr. Mohammed N. Husain ${ }^{* *}$, Haider Salem Jasim ${ }^{* * *}$ \\ *University of Baghdad, engineering college petroleum department, \\ ${ }^{* *}$ Petroleum Research and Development Center, Oil Ministry, \\ ${ }^{* * *}$ Iraqi Drilling Company, Oil Ministry.
}

\section{$\underline{\text { Abstract }}$}

Today oil industry faces a lot of problems and lost money during drilling and completion operation, so that the studies and researches must including the ways and solutions that lead to decrease the costs.

In this research we tried to find local alternative material instead of foreign drilling fluid materials that is used in drilling fluids and will help to save a lot of money by decrease oil well drilling cost because of the high cost of drilling fluid materials which represent now about $30 \%$ of total cost for drilling oil well.

The local alternatives is Ore polymers ( plant origin) called : TRAGACANTH GUM.

In this study we investigated the local material and tested it under API Specification for Drilling Fluids Materials. Also tested sample of mud after add local material (TRAGACANTH GUM.) for weighted concentrations $(0.5,1.5,2,2.5$ and 3 gm.) to show physical and rheological properties.

The third part of this study tested sample of mud after add local material (TRAGACANTH GUM.) under different temperatures values and up to $70^{\circ} \mathrm{C}$ (this temperature is near for some formations temperature in Iraqi oil fields ) to show temperature effect on this material.

A comparison between the local alternative and similar foreign materials for same sample was done to show physical and rheological properties. The results approved that, the local alternatives can used as filtration control materials for water based drilling fluid. Also the local alternatives increased viscosity as minimal for water based drilling fluids, So it can be used as part alternative for Bentonite to increase viscosity by increasing Yield point and 
decreasing solids concentration in drilling fluids so it have positive effect to save Rig equipment's and Pay-zone.

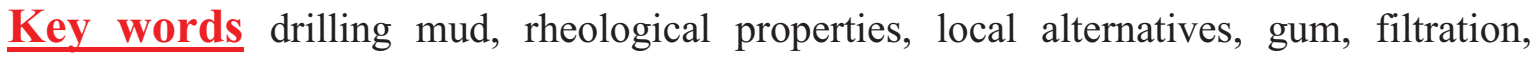
viscosity.

\section{$\underline{\text { Introduction }}$}

\section{Tragacanth Gum: [1-4]}

Tragacanth is a type of natural gum extracted from several species of Middle Eastern legumes of the genus Astragalus, including A. adscendens, A. gummifer, A. brachycalyx, A. microcephalus, A. tragacanthus. Some of these species are known collectively under the common names "goat's thorn" and "locoweed". The name "TRAGACANTH" comes from the appearance of the exuded gum, which tends to form ribbons similar in appearance to a goat thorn (from the Greek "tragos" meaning goat and "akantha" meaning Thorn). The gum is sometimes called shiraz gum, shiraz, gum elect or gum dragon. The primary source of gum tragacanth is the desert highlands of northern and western Iran, particularly the Zagros Mountains region. Iran is the largest producer of best quality Tragacanth gum. In Iran, the gum is harvested seasonally by making an incision on the upper part of the taproot and collecting the exuding gum. The ribbons of gum are brought to trade centers for processing and exportation.
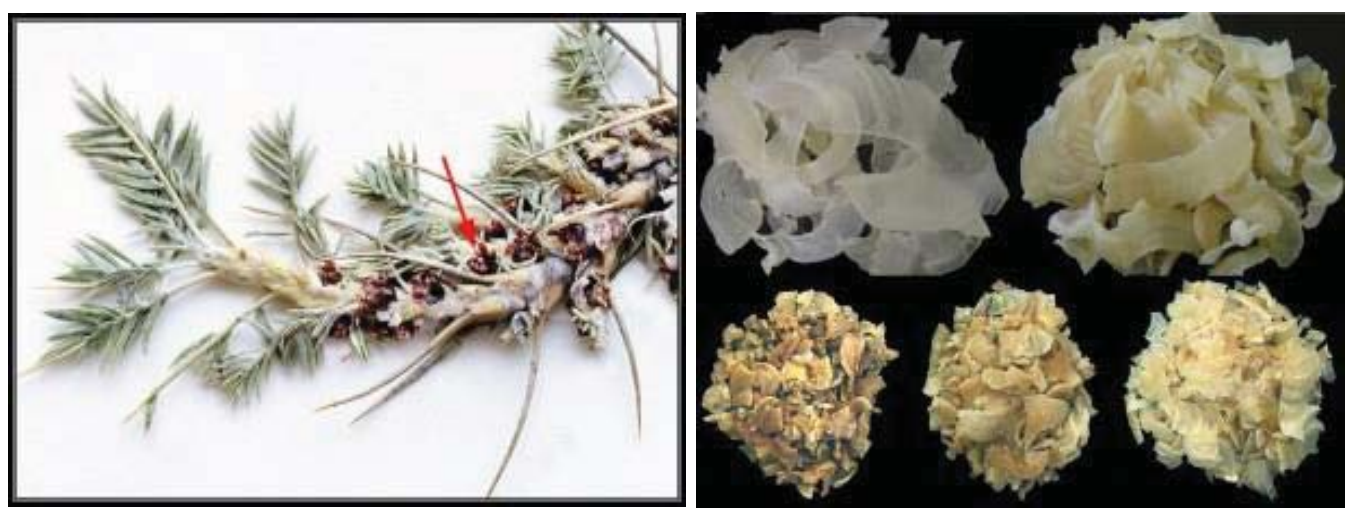

Fig. (1) Tragacanth Gum 


\section{Uses of Tragacanth Gum}

- Gum tragacanth is a viscous, odorless, tasteless, water-soluble mixture of polysaccharides obtained from sap which is drained from the root of the plant and dried.

- The gum seeps from the plant in twisted ribbons or flakes which can be powdered.

- It absorbs water to become a gel, which can be stirred into a paste.

- The gum is used in vegetable-tanned leatherworking as an edge slicking and burnishing compound, and is occasionally used as a stiffener in textiles.

- As a mucilage or paste, it has been used as a topical treatment for burns.

- It is used in pharmaceuticals and foods as an emulsifier, thickener, stabilizer, and texturant additive.

- Gum tragacanth is also used in incense-making as a binder to hold all the powdered herbstogether. Its water solubility is ideal for ease of working and an even spread. Only half as much is needed, compared to gum arabic or something similar

- Gum tragacanth is less common in products than other gums, such as gum arabic or guar gum, largely because most tragacanth is grown in Middle Eastern countries which have shaky trade relations with countries where the gum is to be used.

\section{Properties of Tragacanth Gum}

- Tragacanth contains from $20 \%$ to $30 \%$ of a water-soluble fraction called tragacanthin (composed of tragacanthic acid and arabinogalactan).

- It also contains from $60 \%$ to $70 \%$ of a water-insoluble fraction called bassorin.

- Tragacanthic acid is composed of D-galacturonic acid, D-xylose, L-fructose, Dgalactose, and other sugars.

- Tragacanthin is composed of uronic acid and arabinose and dissolves in water to form a viscous colloidal solution (sol), while bassorin swells to form a thick gel.

- Tragacanthin partially dissolves and partially swells in water yielding a viscous colloid. 
- The maximal viscosity is attained only after 24 hours at room temperature or after heating for 8 hours at high temperatures.

- The viscosity of these solutions is generally considered to be the highest among the plant gums. The solutions are stable to heat and under a wide range of $\mathrm{pH}$ levels.

\section{The differences between Tragacanth Gum and CMC}

The differences between Tragacanth Gum and CMC is explained below.

\section{Tragacanth Gum}

Tragacanth Gum is a substance which is derived from the sap of a plant in the Middle East. The sap is drained from the root of the plant and then dried. This forms a powder which doesn't taste of anything, smells horrible but is ideal for thickening up fondant (also known as sugar paste). The powder is a light cream colour and very fine so one would not want to breathe in too much when smelling it or it can cause one to cough as it enters one's lungs. As Gum Tragacanth is a natural product, we regard it is the "real thing".

CMC

CMC stands for Carboxymethyl cellulose. In short, it is the chemical version of Gum Tragacanth. It looks exactly the same. CMC tends to work a little bit faster than gum tragacanth .

\section{Tragacanth Gum Test}

Physical specifications of tragacanth gum was tested under API Specification 13A. In the first place, the sample tested as CMC - LVT physical specifications standers to show the tragacanth gum behavior as a Filter-loss-control material like CMC the test shows that tragacanth gum is near from CMC -LVT, as shown in table (1) below. 
Table (1) CMC - LVT Physical Specifications Test of Tragacanth Gum

\begin{tabular}{|l|c|c|}
\hline \multicolumn{1}{|c|}{ Requirement } & Standard & Result \\
\hline Starch or starch derivates presence & No & Yes \\
\hline Solution properties & Minimum 90 & 262 \\
\hline Viscometer dial reading at 600 r/min & Maximum 10 & 9.8 \\
\hline Filtrate volume, millilitres &
\end{tabular}

Then, the sample tested as CMC - HVT physical specifications to show if the tragacanth gum (local material) increase the viscosity in minimal or not the test gave a good results, as shown in table (2) below.

Table (2) CMC - HVT Physical Specifications Test of Tragacanth Gum

\begin{tabular}{|c|c|c|}
\hline Requirement & Standard & Result \\
\hline Starch or starch derivates presence & No & Yes \\
\hline \multicolumn{2}{|l|}{} \\
\hline Solution properties & \multicolumn{2}{l}{} \\
\hline Viscometer dial reading at 600 r/min & Minimum 30 & 20 \\
\hline In deionized water & Minimum 30 & 19 \\
\hline In 40 g/l salt solution & Minimum 30 & 27 \\
\hline In saturated salt water & Maximum 10 & 10 \\
\hline Filtrate volume, millilitres
\end{tabular}

In addition, local material was tested as Starch physical specifications, the test confirmed tragacanth gum (local material) as a good Filter-loss-control agent in salt and salt saturated water, as shown in table (3) below. 
Table (3) Starch Physical Specifications Test of Tragacanth Gum

\begin{tabular}{|c|c|c|}
\hline Requirement & Standard & Result \\
\hline Suspension properties & \\
\hline Viscometer dial reading at $600 \mathrm{r} / \mathrm{min}$ \\
\hline In 40 g/l salt water & Maximum 18 & 88 \\
\hline In saturated salt water & Maximum 20 \\
\hline Filtrate volume & Maximum 10 & $\mathbf{8 . 4}$ \\
\hline In 40 g/l salt water, milliliters & Maximum 10 & 7.6 \\
\hline In saturated salt water, milliliters & No residue & \\
\hline Residue greater than $2000 \mu \mathrm{m}$ &
\end{tabular}

Many tests have been done to choose blank sample (sample considered start point for all physical properties). It was included (350 cc water, $20 \mathrm{gm}$ viscosifiers, $0.1 \mathrm{gm}$ sodiym hydroxide).

Table (4) Drilling Fluids Properties of Blank Samples (surface conditions).

\begin{tabular}{|c|c|}
\hline Rheological Properties & Blank Sample \\
\hline R600/R300 & $38 / 33$ \\
\hline R200/R100 & $30 / 27$ \\
\hline R60/R30 & $26 / 25$ \\
\hline R6/R3 & $24 / 24$ \\
\hline AV & 19 \\
\hline PV & 5 \\
\hline YP & 28 \\
\hline YP/PV & 5.6 \\
\hline 10sec/10min Gel & $27 / 33$ \\
\hline Mud Weight & 1.03 \\
\hline API Fluid Loss & 17.6 \\
\hline PH & 9.7 \\
\hline
\end{tabular}


Note: All tests in Laboratory condition and for hydration leave the samples 24 hours before tests.

For comparison, we prepared samples of fresh water bentonite, each of them prepared with the same amount (by weight) of local material (tragacanth gum) and foreign material (M- I PAC UL). The results are explained, in detail, in tables (5) and (6). It should be noted that all tests were surface conditions.

Table (5) Properties of Samples prepared by Fresh Water Bentonite and Tragacanth Gum

\begin{tabular}{|c|c|c|c|c|c|c|c|}
\hline $\begin{array}{c}\text { Rheological } \\
\text { Properties }\end{array}$ & Blank & $\begin{array}{c}0.5 \\
\text { gm }\end{array}$ & $\begin{array}{c}1 \\
\text { gm }\end{array}$ & $\begin{array}{c}1.5 \\
\text { gm }\end{array}$ & $\begin{array}{c}2 \\
\text { gm }\end{array}$ & $\begin{array}{c}2.5 \\
\text { gm }\end{array}$ & $\begin{array}{c}3 \\
\text { gm }\end{array}$ \\
\hline R600/R300 & $38 / 33$ & $59 / 53$ & $70 / 63$ & $84 / 72$ & $98 / 85$ & $117 / 102$ & $155 / 133$ \\
\hline R200/R100 & $30 / 27$ & $51 / 48$ & $61 / 58$ & $68 / 61$ & $79 / 73$ & $92 / 82$ & $122 / 108$ \\
\hline R60/R30 & $26 / 25$ & $46 / 46$ & $56 / 55$ & $58 / 57$ & $70 / 68$ & $78 / 74$ & $103 / 96$ \\
\hline R6/R3 & $24 / 24$ & $45 / 45$ & $54 / 51$ & $55 / 52$ & $67 / 61$ & $64 / 62$ & $90 / 78$ \\
\hline AV & 19 & 29.5 & 35 & 42 & 49 & 58.5 & 77.5 \\
\hline PV & 5 & 6 & 7 & 12 & 13 & 15 & 22 \\
\hline YP & 28 & 47 & 56 & 60 & 72 & 87 & 111 \\
\hline YP/PV & 5.6 & 7.8 & 8 & 5 & 5.5 & 5.8 & 5.1 \\
\hline $\begin{array}{c}\text { 10sec/10min } \\
\text { Gel }\end{array}$ & $27 / 33$ & $40 / 46$ & $49 / 56$ & $48 / 58$ & $56 / 66$ & $60 / 65$ & $69 / 81$ \\
\hline Mud Weight & 1.03 & - & - & - & - & - & - \\
\hline $\begin{array}{c}\text { API Fluid } \\
\text { Loss }\end{array}$ & 17.6 & 13.6 & 12 & 10.4 & 9.2 & 8.8 & 8 \\
\hline PH & 9.7 & 9.7 & 9.7 & 9.5 & 9.2 & 9 & 9 \\
\hline
\end{tabular}


Table (6) Properties of Samples prepared by Fresh Water Bentonite and Foreign Material (M-I PAC UL)

\begin{tabular}{|c|c|c|c|c|c|c|c|}
\hline $\begin{array}{c}\text { Rheological } \\
\text { Properties }\end{array}$ & Blank & $\begin{array}{c}0.5 \\
\text { gm }\end{array}$ & $\begin{array}{c}1 \\
\text { gm }\end{array}$ & $\begin{array}{c}1.5 \\
\text { gm }\end{array}$ & $\begin{array}{c}2 \\
\text { gm }\end{array}$ & $\begin{array}{c}2.5 \\
\text { gm }\end{array}$ & $\begin{array}{c}3 \\
\text { gm }\end{array}$ \\
\hline R600/R300 & $38 / 33$ & $38 / 33$ & $49 / 41$ & $61 / 49$ & $75 / 62$ & $92 / 77$ & $112 / 97$ \\
\hline R200/R100 & $30 / 27$ & $26 / 22$ & $37 / 30$ & $43 / 37$ & $56 / 47$ & $69 / 58$ & $86 / 73$ \\
\hline R60/R30 & $26 / 25$ & $20 / 19$ & $28 / 25$ & $33 / 30$ & $43 / 39$ & $53 / 49$ & $66 / 60$ \\
\hline R6/R3 & $24 / 24$ & $17 / 16$ & $22 / 22$ & $26 / 25$ & $35 / 32$ & $43 / 42$ & $52 / 49$ \\
\hline AV & 19 & 19 & 24.5 & 30.5 & 37.5 & 46 & 56 \\
\hline PV & 5 & 5 & 8 & 12 & 13 & 15 & 15 \\
\hline YP & 28 & 28 & 33 & 37 & 49 & 62 & 82 \\
\hline YP/PV & 5.6 & 5.2 & 4.1 & 3.1 & 3.8 & 4.1 & 5.5 \\
\hline $\begin{array}{c}\text { 10sec/10min } \\
\text { Gel }\end{array}$ & $27 / 33$ & $22 / 42$ & $31 / 53$ & $36 / 57$ & $41 / 70$ & $41 / 78$ & $57 / 86$ \\
\hline Mud Weight & 1.03 & - & - & - & - & - & - \\
\hline $\begin{array}{c}\text { API Fluid } \\
\text { Loss }\end{array}$ & 17.6 & 9.2 & 7.6 & 7.4 & 7.0 & 6.8 & 6.8 \\
\hline PH & 9.7 & 9.2 & 9 & 9 & 9 & 9 & 9 \\
\hline
\end{tabular}

The same test procedure was made on another two foreign material, DUO-VIS and M-I GEL in order to compare apparent viscosity, plastic viscosity and yield point of them with local material, Tragacanth gum, as shown in tables (7) and (8). 
No.21 Journal of Petroleum Research \& Studies

Table (7) Properties of Samples prepared by Fresh Water Bentonite and Foreign Material, (DUO-VIS)

\begin{tabular}{|c|c|c|c|c|c|c|c|}
\hline $\begin{array}{c}\text { Rheological } \\
\text { Properties }\end{array}$ & Blank & $\begin{array}{l}0.5 \\
\text { gm }\end{array}$ & $\begin{array}{c}1 \\
\text { gm }\end{array}$ & $\begin{array}{l}1.5 \\
\mathrm{gm}\end{array}$ & $\begin{array}{c}2 \\
\text { gm }\end{array}$ & $\begin{array}{l}2.5 \\
\mathrm{gm}\end{array}$ & $\begin{array}{c}3 \\
\text { gm }\end{array}$ \\
\hline R600/R300 & $38 / 33$ & $87 / 81$ & $110 / 104$ & $140 / 129$ & $162 / 149$ & $178 / 165$ & $184 / 168$ \\
\hline R200/R100 & $30 / 27$ & $78 / 73$ & 99/92 & $124 / 114$ & $145 / 134$ & $159 / 148$ & $160 / 143$ \\
\hline R60/R30 & $26 / 25$ & $70 / 69$ & $88 / 84$ & 111/107 & $130 / 125$ & $144 / 137$ & $133 / 117$ \\
\hline R6/R3 & $24 / 24$ & $67 / 65$ & $80 / 74$ & 94/87 & 111/83 & $97 / 78$ & $71 / 60$ \\
\hline AV & 19 & 43.5 & 55 & 70 & 81 & 89 & 92 \\
\hline PV & 5 & 6 & 6 & 11 & 13 & 13 & 16 \\
\hline YP & 28 & 75 & 98 & 118 & 136 & 152 & 152 \\
\hline YP/PV & 5.6 & 12.5 & 16.3 & 10.7 & 10.5 & 11.7 & 9.5 \\
\hline $\begin{array}{c}\text { 10sec/10min } \\
\text { Gel }\end{array}$ & $27 / 33$ & $59 / 64$ & $64 / 65$ & $80 / 86$ & $76 / 79$ & $71 / 73$ & $54 / 60$ \\
\hline Mud Weight & 1.03 & - & - & - & - & - & - \\
\hline $\begin{array}{l}\text { API Fluid } \\
\text { Loss }\end{array}$ & 17.6 & 12 & 10.4 & 9.6 & 9.2 & 8.8 & 8 \\
\hline PH & 9.7 & 9.6 & 9.6 & 9.5 & 9.4 & 9.4 & 9.4 \\
\hline
\end{tabular}


Table (8) Properties of Samples prepared by Fresh Water Bentonite and Foreign

Material (M-I Gel)

\begin{tabular}{|c|c|c|c|c|c|c|c|}
\hline $\begin{array}{c}\text { Rheological } \\
\text { Properties }\end{array}$ & Blank & $\begin{array}{c}0.5 \\
\text { gm }\end{array}$ & $\begin{array}{c}1 \\
\text { gm }\end{array}$ & $\begin{array}{c}1.5 \\
\text { gm }\end{array}$ & $\begin{array}{c}2 \\
\text { gm }\end{array}$ & $\begin{array}{c}2.5 \\
\text { gm }\end{array}$ & $\begin{array}{c}3 \\
\text { gm }\end{array}$ \\
\hline R600/R300 & $38 / 33$ & $42 / 38$ & $44 / 41$ & $47 / 42$ & $49 / 46$ & $52 / 48$ & $55 / 49$ \\
\hline R200/R100 & $30 / 27$ & $37 / 34$ & $39 / 37$ & $41 / 38$ & $45 / 41$ & $47 / 45$ & $48 / 47$ \\
\hline R60/R30 & $26 / 25$ & $34 / 32$ & $36 / 35$ & $37 / 36$ & $40 / 40$ & $44 / 42$ & $45 / 44$ \\
\hline R6/R3 & $24 / 24$ & $31 / 31$ & $34 / 33$ & $36 / 35$ & $39 / 38$ & $41 / 40$ & $43 / 42$ \\
\hline AV & 19 & 21 & 22 & 23.5 & 24.5 & 26 & 27.5 \\
\hline PV & 5 & 4 & 3 & 5 & 3 & 4 & 6 \\
\hline YP & 28 & 34 & 38 & 37 & 43 & 44 & 43 \\
\hline YP/PV & 5.6 & 8.5 & 12.7 & 7.4 & 14.3 & 11 & 7.2 \\
\hline $\begin{array}{c}\text { 10sec/10min } \\
\text { Gel }\end{array}$ & $27 / 33$ & $30 / 33$ & $32 / 36$ & $34 / 37$ & $37 / 40$ & $39 / 40$ & $38 / 40$ \\
\hline $\begin{array}{c}\text { Mud } \\
\text { Weight }\end{array}$ & 1.03 & - & - & - & - & - & - \\
\hline $\begin{array}{c}\text { API Fluid } \\
\text { Loss }\end{array}$ & 17.6 & 19.6 & 19.0 & 18.4 & 17.6 & 17.6 & 17.2 \\
\hline \begin{tabular}{c} 
PH \\
\hline
\end{tabular} & 9.7 & 9.0 & 9.0 & 9.0 & 9.0 & 9.0 & 9.0 \\
\hline
\end{tabular}

We have plotted a figures in order to figure out the behavior of the rheological properties that have been shown in tables $(5,6,7$ and 8$)$ as below: 


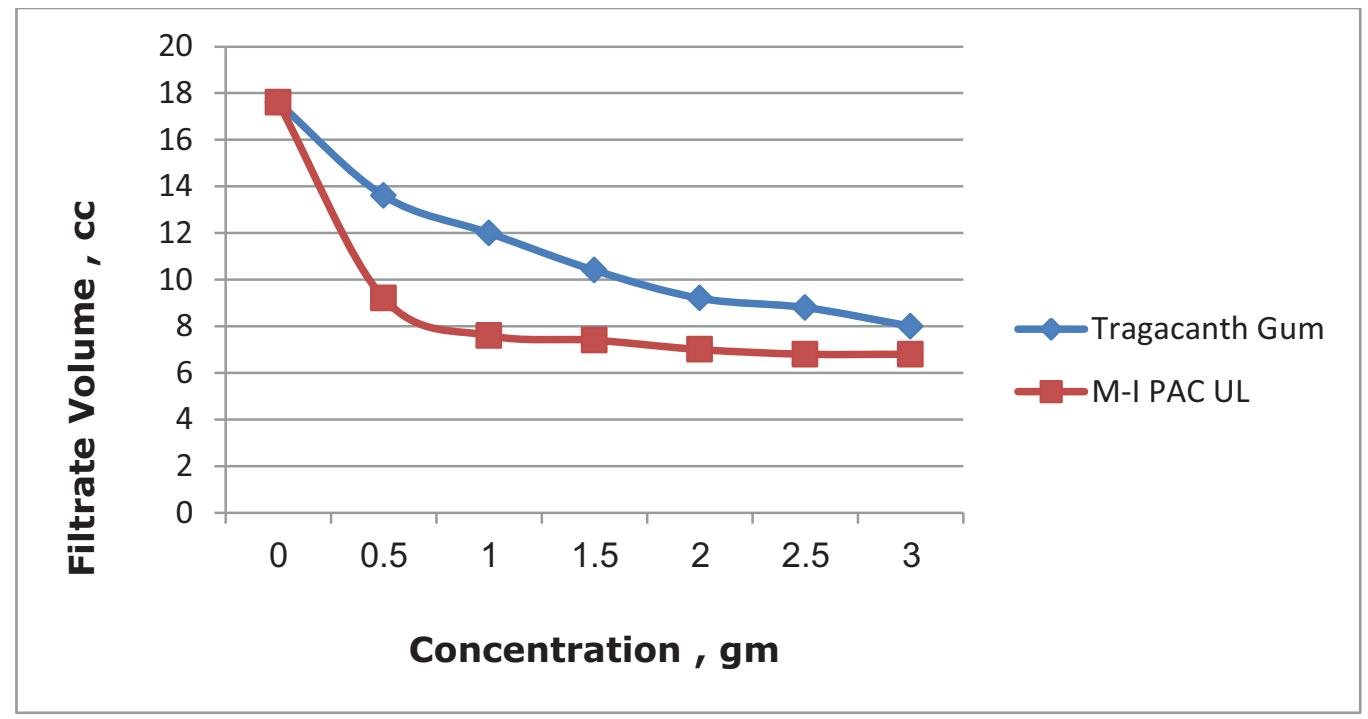

Fig. (2) Effect of additives concentrations on filter loss property for Tragacanth Gum and M-I PAC UL.

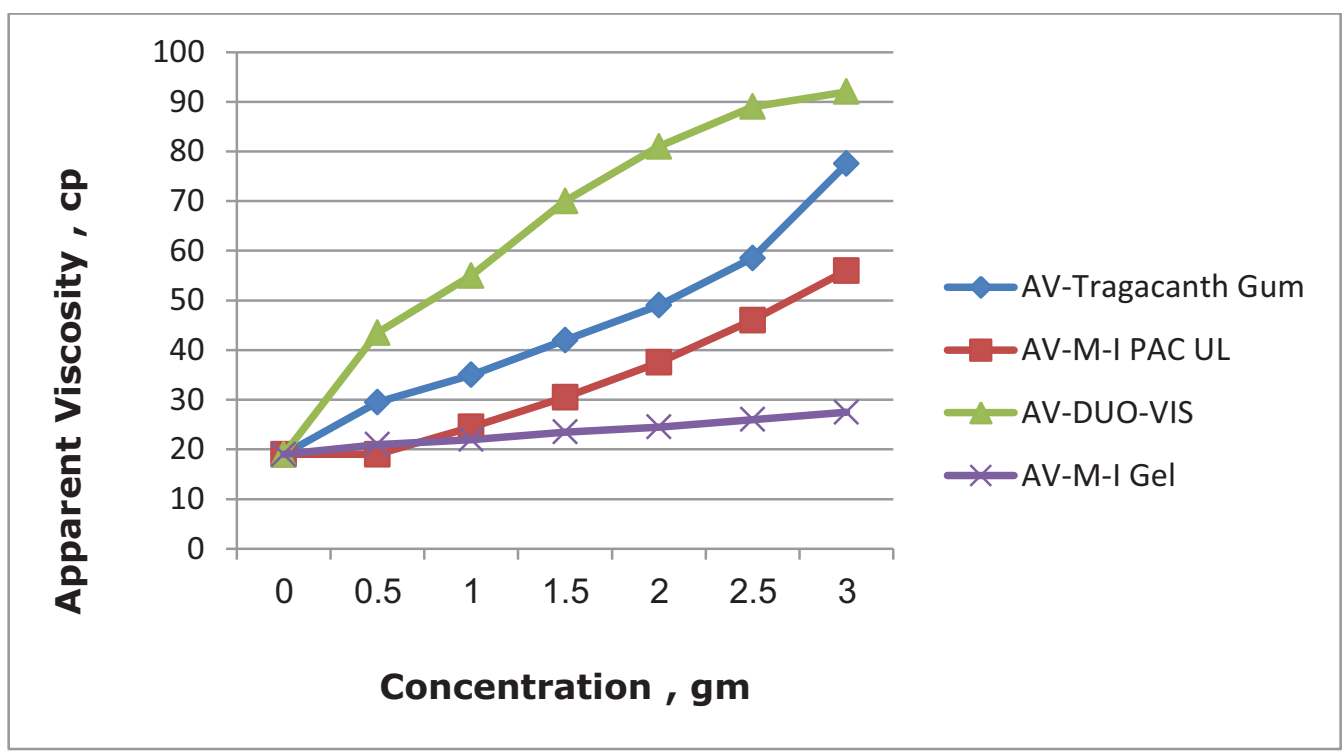

Fig. (3) Effect of additives concentrations on Apparent viscosity (AV) for Tragacanth Gum, M-I PAC UL, DUO-VIS and M-I Gel 


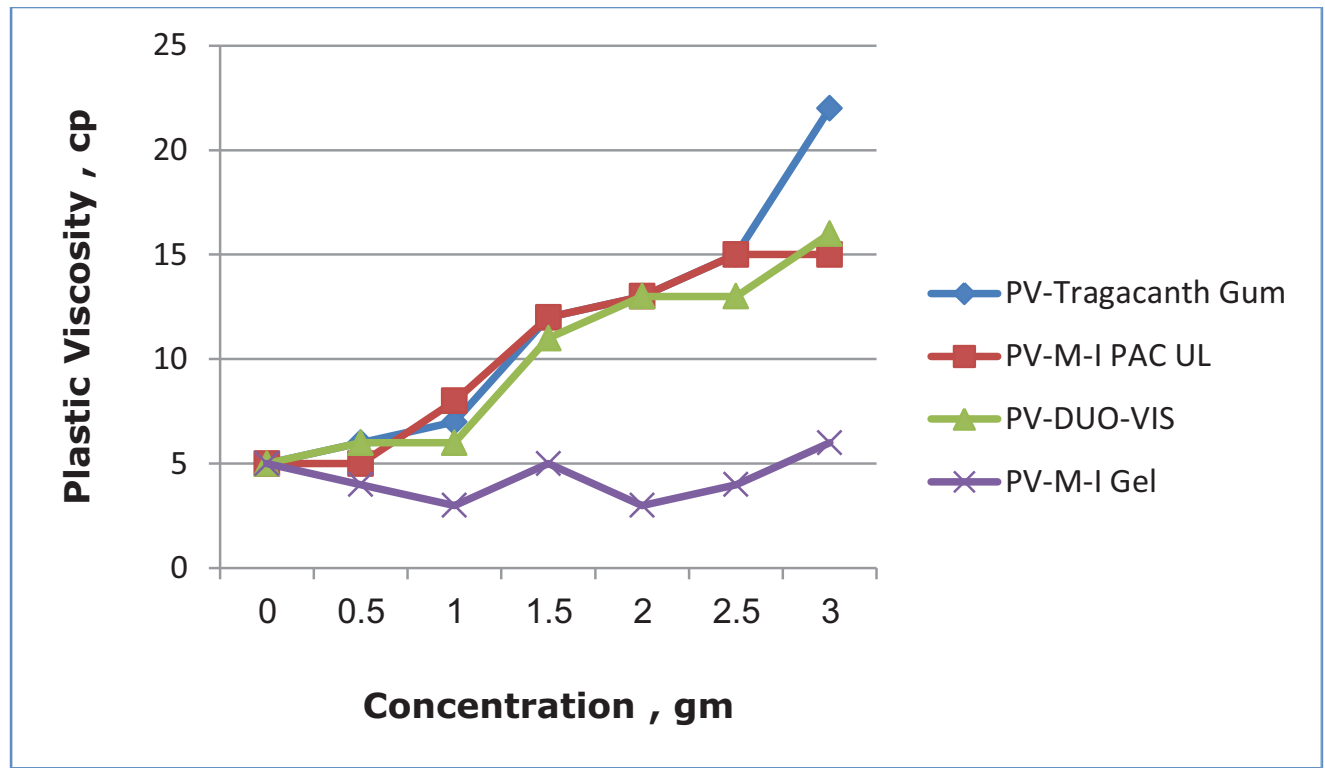

Fig. (4) Effect of additives concentrations on plastic viscosity (PV) for Tragacanth Gum, M-I PAC UL, DUO-VIS and M-I Gel

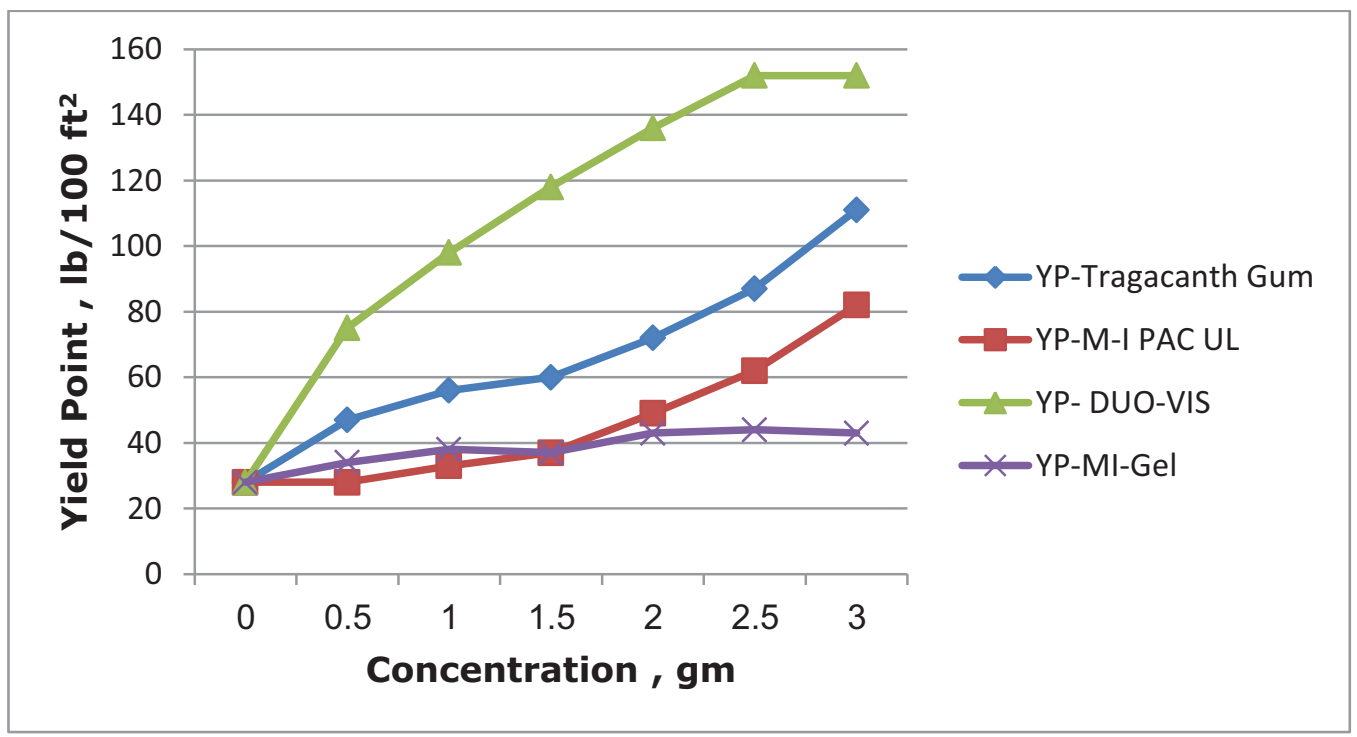

Fig. (5) Effect of additives concentrations on Yield point (YP) for Tragacanth Gum, M-I PAC UL, DUO-VIS and M-I Gel

As shown above in figures, the local material gave a good results as viscosifier (increase in rheological properties with respect to increase the concentration) and as shown in fig. 1 
the local material can be used as filtrate control material because when increase its concentration the filtration amount decreased.

Table (9) The effect of temperature on Rheological Properties of Fresh water bentonite (blank sample) with adding Local Material, Tragacanth Gum (Filter-losscontrol Agent).

\begin{tabular}{|c|c|c|c|c|c|}
\hline $\begin{array}{l}\text { Rheological } \\
\text { Properties }\end{array}$ & $\stackrel{\text { Lab. }}{{ }^{\circ} \mathrm{C}}$ & $\begin{array}{l}40 \\
{ }^{\circ} \mathrm{C}\end{array}$ & $\begin{array}{l}50 \\
{ }^{5} \mathrm{C}\end{array}$ & $\begin{array}{l}60 \\
{ }^{6} \mathrm{C}\end{array}$ & $\begin{array}{l}70 \\
{ }^{\circ} \mathrm{C} \\
\end{array}$ \\
\hline R600/R300 & $98 / 85$ & $130 / 109$ & $137 / 117$ & $153 / 133$ & $170 / 152$ \\
\hline R200/R100 & $79 / 73$ & $100 / 91$ & $109 / 102$ & $126 / 119$ & $131 / 124$ \\
\hline R60/R30 & $70 / 68$ & $87 / 84$ & 99/97 & $115 / 113$ & $123 / 122$ \\
\hline R6/R3 & $67 / 61$ & $80 / 79$ & $94 / 92$ & $109 / 108$ & $119 / 114$ \\
\hline AV & 49 & 65 & 68.5 & 76.5 & 85 \\
\hline PV & 13 & 21 & 20 & 20 & 18 \\
\hline YP & 72 & 88 & 97 & 113 & 134 \\
\hline $\mathrm{YP} / \mathrm{PV}$ & 5.5 & 4.2 & 4.9 & 5.7 & 7.4 \\
\hline $\begin{array}{c}\text { 10sec/10min } \\
\text { Gel }\end{array}$ & $56 / 66$ & $67 / 74$ & $76 / 87$ & $82 / 90$ & $84 / 92$ \\
\hline Mud Weight & 1.03 & - & - & - & - \\
\hline Filter Fluid Loss & 9.2 & - & - & - & - \\
\hline PH & 9.2 & 9.2 & 9.1 & 9.1 & 8.7 \\
\hline
\end{tabular}

Note: Add 2 gm of Tragacanth Gum to blank sample. 


\section{No.21 Journal of Petroleum Research \& Studies}

\section{Conclusions}

1- As shown above we can conclude that Tragacanth Gum gave rheological properties values near from M.I PAC UL values as a filtration control agents in water base mud, Although the Tragacanth Gum are ore polymer and M.I PAC UL are manufacturing polymer, Also its behavior succeeded in deionized, salt and salt saturated water as filter loss agent.

2- Tragacanth Gum gave increase in apparent viscosity, plastic viscosity, and yield point value than M.I PAC UL for same concentrations.

3-As a result of our test for temperature effect on rheological properties we can use this material as filter loss agents in water base mud to drill oil well in Iraqi oil fields. The material show good rheological properties as viscosifier agents, therefore we can advise to use it in preparation drilling mud. 


\section{$\underline{\text { References }}$}

1. http://en.wikipedia.org/wiki/Natural_gum Polysaccharide

2. IUPAC, Compendium of Chemical Terminology, 2nd ed. (the "Gold Book") (1997). Online corrected version:"homopolysaccharide (homoglycan)",2006.

3. http://vasugum.com/tragacanth-gum.

4. "Astragalus brachycalyx Fisch.". Germplasm Resources Information Network (GRIN) online database. Retrieved 24 December 2010. 